\title{
THE INVESTIGATION OF SYMPTOMLESS GLYCOSURIA WITH THE GALACTOSE AND CORTISONE MODIFIED GLUCOSE TOLERANCE TESTS
}

\author{
BY \\ R. B. GOUDIE, W. P. STAMM, AND S. DISCHE \\ From the Royal Air Force Institute of Pathology and Tropical Medicine
}

(RECEIVED FOR PUBLICATION OCTOBER 21, 1957)

Glycosuria is sought in routine clinical examinations in order to detect patients with early or mild diabetes mellitus. There is good evidence that early treatment may avert deterioration and lead to a lower and later incidence of the vascular, renal, and ophthalmic complications (Dunlop, 1954; Ricketts, 1947).

Certain occupations are unsuitable for the diabetic, and early diagnosis is of particular importance in the Royal Air Force because a diagnosis of diabetes is a ban on aircrew duties.

Since other conditions may give rise to glycosuria, its discovery must be followed by a careful investigation in every case to determine the cause. Precision in diagnosis is important in view of the social and economic consequences of a diagnosis of diabetes mellitus, and to provide reliable data for assessing the natural history of the disease and the effects of treatment.

The glucose tolerance test is the most widely used method of determining the significance of symptomless glycosuria. It is based on the fact that after ingesting glucose most patients with frank clinical diabetes have high blood glucose concentrations which are conspicuously abnormal, i.e., they have an impaired tolerance to glucose. By analogy, patients with symptomless glycosuria who have a frankly impaired glucose tolerance when compared with a normal control group are presumed to be diabetic if no other cause for impairment of tolerance can be found. Patients in whom glycosuria is due to a low renal threshold usually exhibit a glucose tolerance which is completely normal. In some cases of glycosuria the glucose tolerance curves are abnormal in certain respects only; in others the curves are abnormal but border on the normal. Controversy exists as to the interpretation to be placed on these curves owing to lack of agreement between authors on the diagnostic criteria to be adopted.
Joslin and Lawrence are two leading authorities $\underset{\infty}{\stackrel{\leftrightarrow}{N}}$ who are representative of the two main schools of 0 thought. Joslin, Root, White, and Marble (1952) gave the following criteria for the diagnosis of $\bar{D}$ diabetes mellitus with the $100 \mathrm{~g}$. glucose tolerance test (" true glucose" technique, capillary blood): a fasting blood glucose over $100 \mathrm{mg} . / 100 \mathrm{ml}$., or a peak glucose value over $170 \mathrm{mg} . / 100 \mathrm{ml}$. He considered that the two-hour level was " of great $\overrightarrow{0}$ value" but that " one cannot disregard the heighe to which the curve goes. In borderline cases it well to be conservative and to repeat the test of a later occasion."

On the other hand, Lawrence (1947) attached maximum importance to the two-hour level, irrespective of the peak value of the curve. Using a 50 g. glucose tolerance test (capillary samples and "total reducing substances"), his figures for the upper limits of normal were: fasting 120 , peak 200 , and two-hour $120 \mathrm{mg} . / 100 \mathrm{ml}$. Subtracting $15 \mathrm{mg}$./100 ml. for conversion to " true glucose "용 values, these figures become fasting 105 , peak 185 , and two-hour $105 \mathrm{mg} . / 100 \mathrm{ml}$. He considered that abnormal peak values were of no importance 8 in the presence of a normal two-hour value, and $₹$ was convinced that diabetes could not be diag- 웅 nosed without a raised two-hour value. He cited as evidence 80 cases observed by himself (1936) and the fact that normal persons given glucose by duodenal tube and post-gastrectomy cases had $O$ abnormally high peaks but normal two-hour $\mathbb{O}$ values. He attributed these "oxyhypergly- N caemic " or "lag" (Maclean, 1922) curves to rapid gastric emptying.

Joslin did not recognize oxyhyperglycaemic $\frac{0}{\Phi}$ curves as constituting a separate group and $\stackrel{\oplus}{?}$ claimed that he had seen such patients with nor- 0 mal two-hour values whom time had shown to be $\overrightarrow{0}$ diabetic.

The present authors felt that although some $\stackrel{?}{\mathbb{Q}}$ 
" oxyhyperglycaemic" curves were due to rapid absorption of glucose, it was likely on a priori grounds that there would be a group in which the same shaped curves were produced by true impairment of glucose tolerance, and that there was a need for further investigation of patients with this type of curve. It was considered that the group of patients with borderline glucose tolerance tests could conveniently be investigated at the same time.

Mosenthal (1947) considered that the intravenous administration of glucose for tolerance testing was advantageous in difficult cases, since irregularities of absorption of glucose from the alimentary tract were avoided. High oral tolerance curves associated with normal intravenous tests do not necessarily indicate rapid intestinal absorption, since Moyer and Womack (1950) demonstrated that the intravenous glucose tolerance test was specific for impairment of glucose tolerance but not very sensitive. There is evidence that the intestinal mucosa may exert an endocrine hyperglycaemic effect during glucose absorption. Laughton and MacCallum (1932) extracted a hyperglycaemia-producing substance from the duodenal mucosa of animals. Loubatières (1954) showed a rise in an alloxan-like substance in the blood after oral administration of glucose; in diabetes a much greater rise occurred. Much less of this substance appeared in the blood of normals and diabetics after intravenous glucose. In view of these observations it was considered that the intravenous glucose tolerance test was unlikely to detect impairment of glucose tolerance of very mild degree and hence would probably be of little value in the diagnosis of patients showing borderline g'ucose tolerance curves.

Research on the use of galactose tolerance tests in parallel with glucose tolerance tests (Dische, Stamm, and Goudie, 1958) showed that the peak galactose value tended to reflect the rate of absorption of ingested glucose, thus allowing a more specific estimate of glucose tolerance independent of absorption.

Fajans and Conn (1954) described a cortisonemodified glucose tolerance test, which, they believed, might unmask the potential diabetic who had normal glucose tolerance by the conventional test.

In the present investigation an attempt has been made to assess the value of the galactose and the cortisone-modified glucose tolerance tests in the diagnosis of patients with glycosuria showing oxyhyperglycaemic and other types of borderline curves in oral glucose tolerance tests. The results of a follow-up on a small series of oxyhyperglycaemic patients are also reported.

\section{Galactose Tolerance Test}

Material and Methods.-Both glucose and galactose tolerance tests have been performed on 65 patients with a history of glycosuria. Eleven were patients requested by us to attend because their previous glucose tolerance tests had shown equivocal results,

TABLE I

DETAILS OF CASES WITH DIABETES, PROBABLE DIABETES, AND PRONOUNCED IMPAIRMENT OF GLUCOSE TOLERANCE

\begin{tabular}{|c|c|c|c|c|c|c|c|c|c|}
\hline \multirow[t]{2}{*}{$\begin{array}{c}\text { Case } \\
\text { Number }\end{array}$} & \multirow[t]{2}{*}{ Age } & \multirow{2}{*}{$\begin{array}{l}\% \\
\text { Expected } \\
\text { Weight }\end{array}$} & \multirow{2}{*}{$\begin{array}{l}\text { Family } \\
\text { History } \\
\text { of } \\
\text { Diabetes }\end{array}$} & \multirow{2}{*}{$\begin{array}{l}\text { Duration } \\
\text { of } \\
\text { Glycosuria }\end{array}$} & \multirow[t]{2}{*}{ Symptoms } & \multicolumn{3}{|c|}{$\begin{array}{l}50 \mathrm{~g} . \text { Glucose' } \\
\text { Tolerance Test } \\
\text { (mg. } 100 \mathrm{ml} .)\end{array}$} & \multirow{2}{*}{$\begin{array}{l}\text { Peak Level } \\
\text { Galactose } \\
\text { Tolerance } \\
\text { Test (mg./ } \\
100 \mathrm{ml} .)\end{array}$} \\
\hline & & & & & & F. & P. & 2 & \\
\hline \multicolumn{10}{|c|}{ Group A: Definite Clinical Diabetes } \\
\hline $\begin{array}{l}1 \\
2 \\
3 \\
4\end{array}$ & $\begin{array}{l}21 \\
24 \\
19 \\
36\end{array}$ & \begin{tabular}{r|}
91 \\
102 \\
93 \\
81
\end{tabular} & $\begin{array}{c}\text { Neg. } \\
,, \\
,,\end{array}$ & $\begin{array}{l}1 \text { month } \\
18 \text { months } \\
4 \stackrel{,}{4},\end{array}$ & $\begin{array}{l}\text { Polydipsia, polyuria } \\
\text { Polyuria, loss of weight } \\
\text { polydipsia, rapid loss of weight, } \\
\text { ketosis }\end{array}$ & $\begin{array}{r}65^{*} \\
87 \\
285 \\
226\end{array}$ & $\begin{array}{l}222 \\
191 \\
440 \\
389\end{array}$ & $\begin{array}{l}191 \\
156 \\
404 \\
320\end{array}$ & $\begin{array}{l}32 \\
54 \\
76 \\
78\end{array}$ \\
\hline 5 & 22 & 94 & , & 1 month & Ketosis, polyuria, loss of weight & 318 & 492 & 492 & 63 \\
\hline \multicolumn{10}{|c|}{ Group B: Probable Clinicial Diabetes } \\
\hline $\begin{array}{l}6 \\
7 \\
8 \\
9\end{array}$ & $\begin{array}{l}39 \\
51 \\
25 \\
50\end{array}$ & $\begin{array}{r}95 \\
112 \\
92 \\
127\end{array}$ & $\begin{array}{c}\text { Neg. } \\
,, \\
,\end{array}$ & 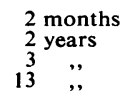 & $\begin{array}{l}\text { Heart block and ketonuria } \\
\text { Mild thirst and polyuria } \\
\text { Loss of } 7 \mathrm{lb} \text {. in weight in } 6 \text { months } \\
\text { Recurrent urinary infection }\end{array}$ & $\begin{array}{l}108 \\
122 \\
179 \\
106\end{array}$ & $\begin{array}{l}212 \\
222 \\
394 \\
252\end{array}$ & $\begin{array}{l}135 \\
142 \\
276 \\
137\end{array}$ & $\begin{array}{l}42 \\
43 \\
86 \\
27\end{array}$ \\
\hline \multicolumn{10}{|c|}{ Group C: Pronounced Impairment of Glucose Tolerance (peak over $185 \mathrm{mg}$, two-hour level over $135 \mathrm{mg}$.) } \\
\hline $\begin{array}{l}10 \\
11 \\
12 \\
13 \\
14\end{array}$ & $\begin{array}{l}40 \\
44 \\
48 \\
36 \\
44\end{array}$ & $\begin{array}{r}110 \\
102 \\
94 \\
127 \\
83\end{array}$ & $\begin{array}{l}\text { Neg. } \\
\text { Mother } \\
\text { Neg. } \\
\text {,, } \\
\text {," }\end{array}$ & $\begin{array}{l}4 \text { months } \\
8 \text { years } \\
4 \text { months } \\
6 \text { years } \\
16 \text {, }\end{array}$ & $\begin{array}{l}\text { None } \\
\quad,, \\
\text { Perspires excessively }\end{array}$ & $\begin{array}{r}125 \\
160 \\
98 \\
192 \\
72\end{array}$ & $\begin{array}{l}274 \\
284 \\
204 \\
300 \\
255\end{array}$ & $\begin{array}{l}184 \\
233 \\
157 \\
266 \\
167\end{array}$ & $\begin{array}{r}70 \\
25 \\
57 \\
9 \\
130\end{array}$ \\
\hline
\end{tabular}

* Received insulin 24 hours before G.T.T. F.=fasting level; P.= peak level; 2 =two-hour level. 
and the remaining 54 were referred for investigation of glycosuria found either during a routine examination or as a result of complaint of symptoms possibly caused by diabetes mellitus. Included in the study were five patients with obvious clinical diabetes, four on whom a diagnosis of "probable clinical diabetes" could be made, and eight who were referred because of glycosuria but who showed no glycosuria during the glucose tolerance test.

On each patient a $50 \mathrm{~g}$. oral glucose tolerance test was carried out using capillary blood and "true" glucose estimations, and on the following day a galactose tolerance test was performed. In each case exactly the same technique was followed as in the normal control series (Dische et al., 1958). Fasting specimens of urine and specimens one and two hours after glucose ingestion were examined by Benedict's qualitative test and the fasting specimen was also examined by Rothera's test. All patients were questioned carefully for present and past symptoms of diabetes. Any past medical history and family history of diabetes were noted. The height and weight were recorded and the weight was also expressed as " percentage of ideal weight " for age, sex, and height from standard insurance tables. A clinical assessment of obesity was also made.
Results.-Tables I, II, and III give a classified list of the most recent glucose tolerance results obtained in the 65 patients with a history of glycosuria investigated, together with their peak galactose values. A brief account of the clinical aspects of each is included.

In order to facilitate comparison between the glucose findings and the galactose tolerance tests, the patients have been classified into groups according to the glucose tolerance results. The normal values mentioned refer throughout to those found in the normal series already reported (Dische et al., 1958).

Group A patients have definite clinical diabetes.

Group $B$ patients probably have clinical diabetes.

Group C patients have no clinical symptoms but pronounced impairment of glucose tolerance with a peak blood glucose level (P) over $185 \mathrm{mg}$./ $100 \mathrm{ml}$. (normal mean +3 S.D.) and a two-hour value (2) over $135 \mathrm{mg}$. $/ 100 \mathrm{ml}$. This two-hour value falls within the range of values observed in patients in Groups A and B who can be con-

TABLE II

DETAILS OF CASES WITH MILD IMPAIRMENT OF GLUCOSE TOLERANCE AND OXYHYPERGLYCAEMIA

\begin{tabular}{|c|c|c|c|c|c|c|c|c|c|}
\hline \multirow[t]{2}{*}{$\begin{array}{c}\text { Case } \\
\text { Number }\end{array}$} & \multirow[t]{2}{*}{ Age } & \multirow[t]{2}{*}{$\begin{array}{c}\% \\
\text { Expected } \\
\text { Weight }\end{array}$} & \multirow{2}{*}{$\begin{array}{l}\text { Family } \\
\text { History } \\
\text { of } \\
\text { Diabeies }\end{array}$} & \multirow{2}{*}{$\begin{array}{l}\text { Duration } \\
\text { of } \\
\text { Glycosuria }\end{array}$} & \multirow[t]{2}{*}{ Symptoms } & \multicolumn{3}{|c|}{$\begin{array}{l}50 \mathrm{~g} . \text { Glucose } \\
\text { Tolerance Test } \\
\text { (mg./100 ml.) }\end{array}$} & \multirow{2}{*}{$\begin{array}{c}\text { Peak Levei } \\
\text { Galactose } \\
\text { Tolerance } \\
\text { Test (mg./ } \\
100 \mathrm{ml} .)\end{array}$} \\
\hline & & & & & & F. & P. & 2 & \\
\hline \multicolumn{10}{|c|}{ Group D: Mild Impairment of Glucose Tolerance (peak over $170 \mathrm{mg} .$, two-hour lovel 106-135 mg.) } \\
\hline \begin{tabular}{l|}
15 \\
16
\end{tabular} & 46 & $\begin{array}{l}103 \\
116\end{array}$ & \begin{tabular}{c|} 
Neg. \\
,$\quad$
\end{tabular} & $\begin{array}{l}2 \text { years } \\
4 \text { months }\end{array}$ & $\begin{array}{l}\text { None } \\
\text { Very doubtful polydipsia and weakness in } \\
\text { tropics } 1 \text { year before glycosuria }\end{array}$ & $\begin{array}{l}101 \\
100\end{array}$ & $\begin{array}{l}190 \\
212\end{array}$ & 134 & $\begin{array}{r}110 \\
10\end{array}$ \\
\hline $\begin{array}{l}17 \\
18\end{array}$ & $\begin{array}{l}24 \\
19\end{array}$ & $\begin{array}{l}86 \\
99\end{array}$ & Grand- & 2 years & $\begin{array}{l}\text { Recurrent boils } \\
\text { None }\end{array}$ & $\begin{array}{r}116 \\
99\end{array}$ & $\begin{array}{l}208 \\
224\end{array}$ & $\begin{array}{l}133 \\
127\end{array}$ & $\begin{array}{l}71 \\
76\end{array}$ \\
\hline 19 & 20 & 114 & $\begin{array}{l}\text { mother } \\
\text { Neg. }\end{array}$ & 18 months & $\begin{array}{l}\text { Glycosuria found during attack of intus- } \\
\text { susception }\end{array}$ & 68 & 195 & 126 & 41 \\
\hline $\begin{array}{l}20 \\
21 \\
22\end{array}$ & $\begin{array}{l}42 \\
19 \\
23\end{array}$ & $\begin{array}{r}117 \\
103 \\
88\end{array}$ & ", & $\begin{array}{l}4 \\
9 \\
1 \text { month }\end{array}$ & $\begin{array}{l}\text { None } \\
\text { Enuresis, fainting attacks } \\
\text { ? Polyuria } \\
\end{array}$ & $\begin{array}{r}80 \\
106 \\
103\end{array}$ & $\begin{array}{l}190 \\
176 \\
225\end{array}$ & $\begin{array}{l}108 \\
128 \\
108\end{array}$ & $\begin{array}{r}52 \\
112 \\
104\end{array}$ \\
\hline \multicolumn{10}{|c|}{ Group E: Oxyhyperglycaemia (peak over $170 \mathrm{mg} .$, two-hour level 80-105 mg.) } \\
\hline $\begin{array}{l}23 \\
24 \\
25 \\
26 \\
27 \\
28 \\
29 \\
30 \\
31\end{array}$ & $\begin{array}{l}32 \\
34 \\
34 \\
60 \\
38 \\
19 \\
36 \\
35 \\
36\end{array}$ & $\begin{array}{r}99 \\
125 \\
120 \\
109 \\
125 \\
96 \\
91 \\
107 \\
\end{array}$ & \begin{tabular}{c|} 
Neg. \\
," \\
," \\
," \\
," \\
,"
\end{tabular} & $\begin{array}{l}3 \text { years } \\
1 \text { month } \\
18 \text { months } \\
20 \text { years } \\
1 \text { month } \\
11 \text { months } \\
1 \text { month } \\
1 \text { year } \\
5 \text { months }\end{array}$ & $\begin{array}{l}\text { None. Trace of ketonuria on two occasions } \\
\text { None } \\
\text {," } \\
\text { Rëcurrent boils } \\
\text { Listlessness } \\
\text { None } \\
\text {," }\end{array}$ & $\begin{array}{r}60 \\
90 \\
82 \\
98 \\
103 \\
87 \\
104 \\
97 \\
101\end{array}$ & $\begin{array}{l}187 \\
194 \\
178 \\
210 \\
191 \\
191 \\
198 \\
180 \\
194\end{array}$ & $\begin{array}{r}82 \\
82 \\
80 \\
100 \\
105 \\
97 \\
83 \\
87 \\
105\end{array}$ & $\begin{array}{r}104 \\
53 \\
70 \\
73 \\
30 \\
65 \\
81 \\
81 \\
101\end{array}$ \\
\hline \multicolumn{10}{|c|}{ Group F: Oxyhyperglycaemia (peak over $170 \mathrm{mg}$. , two-hour level under $80 \mathrm{mg}$.) } \\
\hline $\begin{array}{l}32 \\
33 \\
34 \\
35 \\
36 \\
37 \\
38 \\
39\end{array}$ & $\begin{array}{l}48 \\
38 \\
19 \\
39 \\
43 \\
30 \\
29 \\
36\end{array}$ & \begin{tabular}{|r|}
114 \\
90 \\
104 \\
95 \\
138 \\
93 \\
116 \\
78
\end{tabular} & $\begin{array}{c}\text { Neg. } \\
\text { ", } \\
\text { ", } \\
\text { Mother } \\
\text { Neg. }\end{array}$ & $\begin{array}{l}6 \text { months } \\
1 \text { month } \\
2 \text { months } \\
10 \text { years } \\
10 \text { mönths } \\
7 \text { months } \\
1 \text { month } \\
2 \frac{1}{2} \text { years }\end{array}$ & $\begin{array}{l}\text { Presentation-recurrent boils } \\
\text { None } \\
\text {,", } \\
,, \\
\text { Nöne. Does not appear obese } \\
\text { None. Cholesterol } 312 \mathrm{mg} . / 100 \mathrm{ml} \text {. Liver } \\
\text { function tests normal }\end{array}$ & $\begin{array}{r}91 \\
88 \\
82 \\
104 \\
102 \\
91 \\
101 \\
93\end{array}$ & $\begin{array}{l}200 \\
199 \\
184 \\
179 \\
192 \\
174 \\
174 \\
257\end{array}$ & $\begin{array}{l}66 \\
59 \\
65 \\
75 \\
72 \\
66 \\
52 \\
48\end{array}$ & $\begin{array}{r}90 \\
99 \\
140 \\
120 \\
82 \\
115 \\
96 \\
164\end{array}$ \\
\hline 40 & 18 & $\begin{array}{l}101 \\
101\end{array}$ & ", & $\begin{array}{l}4 \text { months } \\
1 \text { month }\end{array}$ & None & $\begin{array}{l}85 \\
82\end{array}$ & $\begin{array}{l}175 \\
176\end{array}$ & $\begin{array}{l}73 \\
52\end{array}$ & $\begin{array}{l}68 \\
92\end{array}$ \\
\hline
\end{tabular}


TABLE III

DETAILS OF CASES WITH RENAI GLYCOSURIA AND CASES REFERRED WITH GLYCOSURIA BUT IN WHICH NO GLYCOSURIA WAS FOUND DURING GLUCOSE TOLERANCE TEST

\begin{tabular}{|c|c|c|c|c|c|c|c|c|c|}
\hline \multirow[t]{2}{*}{$\begin{array}{c}\text { Case } \\
\text { Number }\end{array}$} & \multirow[t]{2}{*}{ Age } & \multirow{2}{*}{$\begin{array}{l}\% \\
\text { Expected } \\
\text { Weight }\end{array}$} & \multirow{2}{*}{$\begin{array}{l}\text { Family } \\
\text { History of } \\
\text { Diabetes }\end{array}$} & \multirow{2}{*}{$\begin{array}{c}\text { Duration } \\
\text { of } \\
\text { Glycosuria }\end{array}$} & \multirow[t]{2}{*}{ Symptoms } & \multicolumn{3}{|c|}{$\begin{array}{l}50 \mathrm{~g} . \text { Glucose } \\
\text { Tolerance Test } \\
\text { (mg. } / 100 \mathrm{ml} .)\end{array}$} & \multirow{2}{*}{$\begin{array}{c}\text { Peak Level } \\
\text { Galactose } \\
\text { Tolerance } \\
\text { Test (mg.! } \\
100 \mathrm{ml} .)\end{array}$} \\
\hline & & & & & & F. & P. & 2 & \\
\hline \multicolumn{10}{|c|}{ Group G: Renal Glycosuria (peak level under $170 \mathrm{mg} .$, two-hour level under $105 \mathrm{mg} . / 100 \mathrm{ml})}$. \\
\hline $\begin{array}{l}42 \\
43 \\
44 \\
45 \\
46 \\
47 \\
48 \\
49 \\
50 \\
51 \\
52 \\
53 \\
54 \\
55\end{array}$ & $\begin{array}{l}39 \\
21 \\
20 \\
18 \\
25 \\
19 \\
19 \\
32 \\
20 \\
19 \\
21 \\
18 \\
31 \\
43\end{array}$ & $\begin{array}{r}117 \\
94 \\
113 \\
100 \\
91 \\
102 \\
110 \\
118 \\
110 \\
93 \\
91 \\
86 \\
-\end{array}$ & $\begin{array}{l}\text { Neg. } \\
\text { ? Father } \\
\text { Neg. } \\
\text { Brother } \\
\text { Neg. } \\
\text {," } \\
\text { ", } \\
\text { Aunt } \\
\text { Neg. } \\
\text {," } \\
\text { ", } \\
\text {," }\end{array}$ & \begin{tabular}{||l|}
10 years \\
1 month \\
4 months \\
5 ,, \\
4 years \\
4 months \\
1 year \\
1 ," \\
1 month \\
2 years \\
1 month \\
1 ," \\
4 years \\
13 ,"
\end{tabular} & $\begin{array}{l}\text { None } \\
,, \\
, \\
,, \\
,, \\
, \\
, \\
\text { ? P’olyuria } \\
\text { ? Hypoglyca emic attacks } \\
\text { None }\end{array}$ & $\begin{array}{r}91 \\
77 \\
86 \\
83 \\
70 \\
85 \\
84 \\
91 \\
83 \\
71 \\
84 \\
103 \\
85 \\
79\end{array}$ & $\begin{array}{l}170 \\
140 \\
137 \\
108 \\
145 \\
156 \\
127 \\
164 \\
147 \\
156 \\
155 \\
150 \\
146 \\
145\end{array}$ & $\begin{array}{l}70 \\
72 \\
92 \\
85 \\
68 \\
95 \\
98 \\
88 \\
82 \\
49 \\
76 \\
78 \\
47 \\
69\end{array}$ & $\begin{array}{r}68 \\
158 \\
49 \\
11 \\
50 \\
85 \\
28 \\
75 \\
15 \\
80 \\
83 \\
86 \\
94 \\
54\end{array}$ \\
\hline \multicolumn{10}{|c|}{ Group H: Renal Glycosuria (two-hour level over $105 \mathrm{mg} . / 100 \mathrm{ml}$.) } \\
\hline $\begin{array}{l}56 \\
57\end{array}$ & $\begin{array}{l}25 \\
19\end{array}$ & $\begin{array}{l}116 \\
104\end{array}$ & $\begin{array}{l}\text { Neg. } \\
\text { ? Father, } \\
\text { brother, } \\
\text { grandfather }\end{array}$ & $\mid \begin{array}{c}1 \text { month } \\
\text {," }\end{array}$ & $\begin{array}{l}\text { None } \\
\text { None. Acetone reported in urine on } \\
\text { one occasion at another laboratory }\end{array}$ & $\begin{array}{l}72 \\
75\end{array}$ & $\begin{array}{l}149 \\
146\end{array}$ & $\begin{array}{l}116 \\
137\end{array}$ & $\begin{array}{l}59 \\
66\end{array}$ \\
\hline \multicolumn{10}{|c|}{ Group J: Investigation for Glycosuria but no Glycosuria Found } \\
\hline $\begin{array}{l}58 \\
59 \\
60 \\
61 \\
62 \\
63 \\
64 \\
65\end{array}$ & $\begin{array}{l}33 \\
18 \\
36 \\
23 \\
19 \\
27 \\
21 \\
50\end{array}$ & $\begin{array}{r}95 \\
106 \\
113 \\
112 \\
100 \\
95 \\
98 \\
117\end{array}$ & $\begin{array}{l}\text { Neg. } \\
\text {,", } \\
\text {," } \\
\text {," } \\
\text { Grandmother }\end{array}$ & $\left|\begin{array}{lc|}1 & \text { year } \\
1 & \text { month } \\
1 & ,, \\
1 & , \\
1 & , " \\
1 & , " \\
1 & , "\end{array}\right|$ & $\begin{array}{l}\text { Very doubtful polyuria } \\
\text { Frequency of micturition } \\
\text { Recurrent boils } \\
\text { None } \\
\text {,", } \\
\text { ", } \\
\text { Boils and carbuncles }\end{array}$ & $\begin{array}{r}111 \\
91 \\
91 \\
77 \\
70 \\
90 \\
78 \\
95\end{array}$ & $\begin{array}{l}169 \\
140 \\
136 \\
138 \\
138 \\
134 \\
106 \\
175\end{array}$ & $\begin{array}{r}95 \\
90 \\
92 \\
57 \\
103 \\
50 \\
100 \\
71\end{array}$ & $\begin{array}{r}94 \\
20 \\
25 \\
8 \\
55 \\
78 \\
20 \\
38\end{array}$ \\
\hline
\end{tabular}

F. =fasting level P. = peak level $; 2=$ two-hour level.

sidered to have clinically significant impairment of glucose tolerance.

Group D patients have mild impairment of glucose tolerance with a peak value over $170 \mathrm{mg}$./ $100 \mathrm{ml}$. (normal mean +2 S.D.) and a two-hour blood glucose level of between $106 \mathrm{mg} . / 100 \mathrm{ml}$. (normal mean +2 S.D.) and $135 \mathrm{mg} . / 100 \mathrm{ml}$.

Group E patients have a peak over $170 \mathrm{mg}$./ $100 \mathrm{ml}$., and a two-hour level of 80 to $105 \mathrm{mg}$./ $100 \mathrm{ml}$.

Group F patients have a peak over $170 \mathrm{mg}$. $100 \mathrm{ml}$., and a two-hour level under $80 \mathrm{mg} . /$ $100 \mathrm{ml}$.

These two groups ( $E$ and $F$ ) both correspond roughly to Maclean's “ lag " or Lawrence's “ oxyhyperglycaemic" curves (Maclean, 1922; Lawrence, 1936). The subdivision of cases with abnormal peak values and normal two-hour values into two groups (two-hour level above and below the normal mean of $80 \mathrm{mg} . / 100 \mathrm{ml}$.) is based on the authors' observation of the inverse relationship of peak and two-hour levels of blood glucose in the normal control series (Dische et al., 1958).

Group G patients have "renal " glycosuria with a peak glucose value under $170 \mathrm{mg} . / 100 \mathrm{ml}$. and a two-hour value under $105 \mathrm{mg}$. $/ 100 \mathrm{ml}$.
Group H patients have "renal" glycosuria (peak under $170 \mathrm{mg} . / 100 \mathrm{ml}$.) but an abnormal two-hour value (105 mg./100 ml. or more).

Group J patients are those who were referred because of glycosuria but had no glycosuria at the time of the glucose tolerance test.

Table IV gives mean galactose peak results and Fig. 1 shows the frequency distribution of galactose peak levels in the different groups, classified according to the glucose tolerance test. There is

TABLE IV

MEAN GALACTOSE PEAK LEVELS IN GROUPS OF PATIENTS STUDIED

\begin{tabular}{|c|c|c|c|c|c|c|}
\hline \multicolumn{4}{|c|}{$\begin{array}{c}\text { Group } \\
\text { (see Tables I, II, and III) }\end{array}$} & $\begin{array}{l}\text { Number } \\
\text { of } \\
\text { Cases }\end{array}$ & $\begin{array}{l}\text { Mean } \\
\text { (mg./ } \\
100 \mathrm{ml} .)\end{array}$ & $\begin{array}{l}\text { S.E. } \\
\text { of Mean }\end{array}$ \\
\hline $\begin{array}{l}\mathbf{A} \ldots \\
\mathbf{B} \ldots \\
\mathbf{C} \ldots \\
\mathbf{D} \ldots \\
\mathbf{E} \ldots \\
\mathbf{F} \ldots \\
\mathbf{G} \ldots \\
\mathbf{H} \ldots \\
\mathbf{J} \ldots\end{array}$ & $\begin{array}{l}\ldots \\
\cdots \\
\ldots \\
\cdots \\
\cdots \\
\cdots \\
\cdots\end{array}$ & $\begin{array}{l}\cdots \\
\cdots \\
\cdots \\
\cdots \\
\cdots \\
\cdots \\
\cdots\end{array}$ & $\begin{array}{l}\cdots \\
\cdots \\
\cdots \\
\cdots \\
\cdots \\
\cdots \\
\cdots\end{array}$ & $\begin{array}{r}5 \\
4 \\
5 \\
8 \\
9 \\
10 \\
14 \\
2 \\
8\end{array}$ & $\begin{array}{r}60.6 \\
49 \cdot 5 \\
58 \cdot 2 \\
72 \cdot 0 \\
73 \cdot 1 \\
106 \cdot 6 \\
66 \cdot 9 \\
62 \cdot 5 \\
42 \cdot 2\end{array}$ & $\begin{array}{r}14.4 \\
16.1 \\
14.4 \\
11.4 \\
10.7 \\
10.2 \\
8.6 \\
22.8 \\
11.4\end{array}$ \\
\hline \multicolumn{4}{|c|}{ 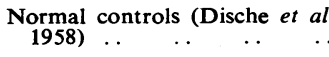 } & 37 & 65.0 & 4.9 \\
\hline \multicolumn{4}{|c|}{$\begin{array}{l}\text { Post-gastrectomy group (Disch } \\
\text { et al., 1958) } \ldots\end{array}$} & 7 & $114 \cdot 0$ & $4 \cdot 3$ \\
\hline
\end{tabular}




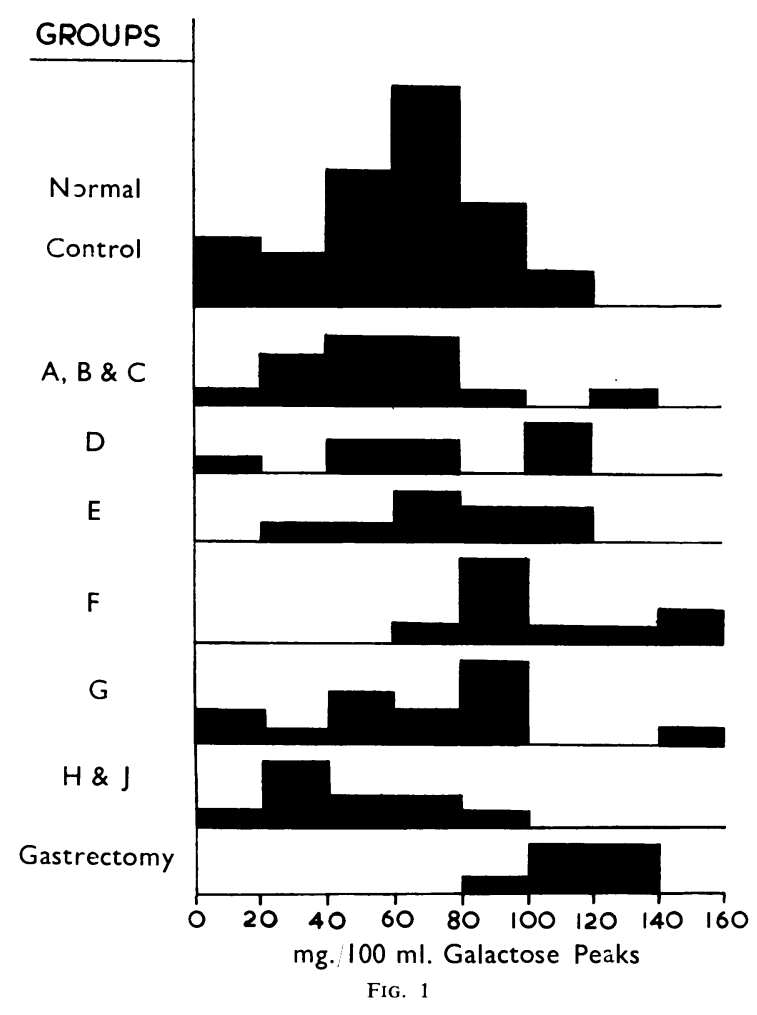

no significant difference between the peak galactose values obtained in the normal control series and those in Groups A, B, C, D, E, G, H, and J, but a highly significant difference $(P<0.001)$ exists between normals and Group F, this being similar to that between normals and the post-gastrectomy patients reported in a previous paper (Dische et al., 1958). There is no significant difference between galactose peak values in Group $F$ and in postgastrectomy cases.

The possibility that a dose-body-weight relationship might affect galactose tolerance results has been discussed previously and considered an unlikely contingency (Dische et al., 1958). In this series the question does not in fact arise since the mean percentage of expected weight of patients in Group F was 103, while that in the normal group was 102 .

\section{Cortisone Modified Glucose Tolerance Test (C.G.T.T.)}

The technique of Fajans and Conn (1954) has been applied in a series of 27 patients with glycosuria, five of whom had a family history of diabetes, and in 21 normal controls with no such family history.

Method.-After three days on a standard diet the fasting patient was given $1.75 \mathrm{~g}$. of glucose per $\mathrm{kg}$. ideal body weight as a "base line " test. The next morning a second glucose tolerance test was performed in identical manner, but the patient had received priming doses of cortisone. Subjects weighing less than $160 \mathrm{lb}$. were given $50 \mathrm{mg}$. of cortisone acetate orally eight and a half hours and two hours before the ingestion of glucose ; those weighing more than $160 \mathrm{lb}$. were given $62.5 \mathrm{mg}$. cortisone acetate at the same time intervals. The original technique was followed with the following differences.

(1) Venous blood glucose was estimated in duplicate by a modification of the Folin and Wu method (Dische, 1955) instead of by Somogyi's method.

(2) The glucose was dissolved in $600 \mathrm{ml}$. of water instead of $400 \mathrm{ml}$. (Fajans, 1956).

(3) "Cortisyl" (Roussel's brand of cortisone acetate) was used instead of that made by Upjohn Co. and Merck and Co.

Interpretation of Results.-Fajans and Conn regarded patients as definitely non-diabetic if they had a two-hour venous blood glucose level under $110 \mathrm{mg} . / 100 \mathrm{ml}$. in the base line test; those witho a two-hour level over $120 \mathrm{mg}$./100 ml. were con-0 sidered diabetic, and those with a two-hour level of 110 to $120 \mathrm{mg}$./100 ml. as " probably diabetic." In the present series a two-hour level of $115 \mathrm{mg}$./ $100 \mathrm{ml}$. or more in the base line test has been assumed to indicate probable diabetes (mean +3 S.D. of two-hour levels in normal control base line tests).

Fajans and Conn considered the response to cortisone to be positive in patients with a normal base line test, if the two-hour level in the C.G.T.T. rose to $140 \mathrm{mg}$. $/ 100 \mathrm{ml}$. or more ; from this control series (Table V) a two-hour level of $130 \mathrm{mg}$./ $100 \mathrm{ml}$. or more in the C.G.T.T. of non-diabetics has been adopted as indicating a positive response (mean +3 S.D. of two-hour levels in the C.G.T.T. control series).

Criteria for a "positive" cortisone response in diabetes were not given by Fajans and Conn, who were mainly concerned with potential diabetics, i.e., patients with a family history of diabetes, who had normal "base line" glucose tolerance tests. They showed, however, in composite curves that in 12 diabetics the mean two-hour level was $40 \mathrm{mg}$. $/ 100$ $\mathrm{ml}$. higher in the C.G.T.T. than in the "base line" test and this has been adopted as the criterion of a positive response in the probable diabetics (diagnosed on the baseline G.T.T. two-hour value). It was not possible to assess the significance of rises of less than $40 \mathrm{mg} . / 100 \mathrm{ml}$., though it is clear that when no rise occurs the result is negative. 
Results.-Table V shows the mean and standard deviation of glucose levels in the base line and cortisone glucose tolerance tests (C.G.T.T.) in 21 normal controls with no family history of diabetes.

\section{TABLE V}

COMPARISON OF RESULTS OF 1.75 G./KG. BASE LINE GLUCOSE TOLERANCE AND CORTISONE GLUCOSE TOLERANCE TESTS IN NORMAL SUBJECTS WITH NO FAMILY HISTORY OF DIABETES MELLITUS WITH SERIES OF FAJANS AND CONN

\begin{tabular}{|c|c|c|c|c|c|c|}
\hline & \multirow[t]{2}{*}{$\begin{array}{c}\text { No. } \\
\text { of } \\
\text { Cases }\end{array}$} & \multirow[t]{2}{*}{$\begin{array}{c}\text { Mean } \\
\text { Age } \\
\text { (years) }\end{array}$} & \multicolumn{2}{|c|}{$\begin{array}{l}\text { Two-Hour } \\
\text { Venous Blood } \\
\text { Glucose } \\
\text { "Base Line" } \\
\text { (mg./100 ml.) }\end{array}$} & \multicolumn{2}{|c|}{$\begin{array}{c}\text { Two-Hour } \\
\text { Venous Blood } \\
\text { Glucose, } \\
\text { Cortisone G.T.T. } \\
\text { (mg./100 ml.) }\end{array}$} \\
\hline & & & Mean & S.D. & Mean & S.D. \\
\hline $\begin{array}{l}\text { Present series .. } \\
\text { Fajans and Connn }\end{array}$ & $\begin{array}{l}21 \\
37\end{array}$ & $\begin{array}{l}24 \\
28\end{array}$ & $\begin{array}{l}73 \cdot 5 \\
90\end{array}$ & $\begin{array}{c}13 \cdot 7 \\
?\end{array}$ & $\begin{array}{c}82 \cdot 3 \\
103\end{array}$ & $\begin{array}{l}15 \cdot 2 \\
12 \cdot 4\end{array}$ \\
\hline
\end{tabular}

The results of the C.G.T.T.s in the 27 glycosurics are shown in Tables VI and VII. Twentyone of these patients had also taken part in the galactose tolerance investigation, and their code numbers are the same as in Tables I, II, and III. The six patients who did not have a galactose tolerance test have been allotted code numbers followed by the letter " $\mathrm{C}$."

TABLE VI

RESULTS OF BASE LINE AND CORTISONE GLUCOSE TOLERANCE TESTS ON NINE PROBABLE DIABETICS

\begin{tabular}{|c|c|c|c|c|}
\hline \multirow{2}{*}{$\begin{array}{c}\text { Case } \\
\text { Number }\end{array}$} & \multicolumn{2}{|c|}{$\begin{array}{l}\text { Two-Hour Venous } \\
\text { Blood Lovel (mg. } \\
\text { per } 100 \mathrm{ml} \text {.) }\end{array}$} & \multirow{2}{*}{$\begin{array}{c}\text { Rise in } \\
\text { Two-Hour } \\
\text { Level on } \\
\text { Cortisone }\end{array}$} & \multirow{2}{*}{$\begin{array}{c}\text { Assessment } \\
\text { of Cortisone } \\
\text { Response } \\
\text { (Positive }=\text { Rise }> \\
40 \mathrm{mg} \text {. per } 100 \mathrm{ml} .)\end{array}$} \\
\hline & $\begin{array}{c}\text { Base Line } \\
\text { Test }\end{array}$ & $\begin{array}{l}\text { Cortisone } \\
\text { G.T.T. }\end{array}$ & & \\
\hline $\begin{array}{l}1 C^{*} \\
2 C \\
9 \\
17 \\
22 \\
27 \\
31 \\
58 \\
65^{*}\end{array}$ & $\begin{array}{l}115 \\
164 \\
127 \\
152 \\
124 \\
122 \\
122 \\
139 \\
126\end{array}$ & $\begin{array}{l}144 \\
192 \\
119 \\
211 \\
145 \\
131 \\
124 \\
132 \\
113\end{array}$ & $\begin{array}{r}+29 \\
+28 \\
-8 \\
+59 \\
+21 \\
+9 \\
+2 \\
-7 \\
-13\end{array}$ & $\begin{array}{c}? \\
? \\
\text { Negative } \\
\text { Positive } \\
? \\
? \\
? \\
\text { Negative } \\
\text {,, }\end{array}$ \\
\hline
\end{tabular}

One of the nine probable diabetics showed a clear-cut positive cortisone response, but in five the rise in the two-hour level after cortisone was negligible or non-existent. Only one of the 18 nondiabetics showed a positive response.

It will be noted that the probable diagnosis based on the venous blood glucose two-hour level following a $1.75 \mathrm{~g} . / \mathrm{kg}$. oral dose of glucose differs in many cases from that made on the $50 \mathrm{~g}$. oral glucose tolerance test (cf. Tables I, II, and III). This point is further discussed below.
TABLE VII

RESULTS OF BASE LINE AND CORTISONE GLUCOSE TOLERANCE TESTS ON 18 NON-DIABETICS INVESTIGATED FOR GLYCOSURIA

\begin{tabular}{|c|c|c|c|}
\hline \multirow{2}{*}{$\begin{array}{l}\text { Case } \\
\text { Number }\end{array}$} & \multicolumn{2}{|c|}{$\begin{array}{l}\text { Two-Hour Venous Blood } \\
\text { Level (mg. per } 100 \mathrm{ml} .)\end{array}$} & \multirow{2}{*}{$\begin{array}{l}\text { Assessment of Cortisone } \\
\text { Response } \\
\text { (Positive= Two-hr. Lovel } \\
>130 \mathrm{mg} \text {. per } 100 \mathrm{ml} \text { ) }\end{array}$} \\
\hline & $\begin{array}{c}\text { Base Line } \\
\text { Test }\end{array}$ & $\begin{array}{l}\text { Cortisone } \\
\text { G.T.T. }\end{array}$ & \\
\hline $\begin{array}{l}3 C^{2} \\
4 C^{*} \\
5 C^{*} \\
6 C^{*} \\
15 \\
19 \\
21 \\
28 \\
35 \\
36 \\
37 \\
39 \\
41 \\
42 \\
53 \\
54 \\
55 \\
57 *\end{array}$ & $\begin{array}{r}74 \\
99 \\
85 \\
79 \\
92 \\
106 \\
97 \\
79 \\
105 \\
114 \\
86 \\
84 \\
44 \\
114 \\
63 \\
65 \\
80 \\
82\end{array}$ & $\begin{array}{r}99 \\
108 \\
92 \\
91 \\
83 \\
109 \\
106 \\
104 \\
51 \\
84 \\
87 \\
163 \\
82 \\
115 \\
57 \\
76 \\
75 \\
121\end{array}$ & $\begin{array}{c}\text { Negative } \\
\text {,, } \\
\text {,, } \\
\text {,, } \\
\text {,, } \\
\text {,, } \\
\text { Positive } \\
\text { Negative } \\
\text {,, } \\
\text {,, } \\
\text {,, } \\
\text {,, }\end{array}$ \\
\hline
\end{tabular}

* Family history of diabetes.

\section{Follow-up Series of Patients with Oxyhyperglycaemia}

A postal follow-up of 29 patients with oxyhyperglycaemia who had left the service resulted in 14 replies. One had died from essential hypertension and left heart failure. The others were to their knowledge free from diabetes though the mean period since glycosuria had been found was 10 years. Nevertheless, when a further nine patients whose tolerance curves had been confidently labelled oxyhyperglycaemic and who were still in the Service were retested, it was found that two had pronounced impairment of glucose tolerance (Cases 11 and 66, Table VIII). Case 66 had persistent ketonuria.

TABLE VIII

REPEATED GLUCOSE TOLERANCE TESTS SHOWING RELATIONSHIP BETWEEN OXYHYPERGLYCAEMIA AND IMPAIRMENT OF GLUCOSE TOLERANCE

\begin{tabular}{|c|c|c|c|c|c|}
\hline \multirow{2}{*}{$\begin{array}{l}\text { Case } \\
\text { No. }\end{array}$} & \multirow{2}{*}{$\begin{array}{l}\text { Date } \\
\text { of Test }\end{array}$} & \multicolumn{3}{|c|}{$\begin{array}{l}\text { Blood Glucose } \\
(\mathrm{mg} . \%)\end{array}$} & \multirow{2}{*}{ Comment } \\
\hline & & $\begin{array}{c}\text { Fast- } \\
\text { ing }\end{array}$ & Peak & $\begin{array}{l}\text { Two- } \\
\text { Hour }\end{array}$ & \\
\hline 11 & $\begin{array}{ll}\text { Jan., } & 1949 * \\
\text { April, } & 1955 \\
\text { May, } 1955\end{array}$ & $\begin{array}{r}71 \\
172 \\
160 \\
85\end{array}$ & $\begin{array}{l}201 \\
296 \\
284\end{array}$ & $\begin{array}{r}81 \\
236 \\
233\end{array}$ & \\
\hline 66 & $\begin{array}{l}\text { Dec., 1949* } \\
\text { Jan., 1949* } \\
\text { April, } 1955 \\
\text { July, } 1955\end{array}$ & $\begin{array}{r}85 \\
96 \\
240 \\
148\end{array}$ & $\begin{array}{l}195 \\
217 \\
550 \\
316\end{array}$ & $\begin{array}{r}135 \\
82 \\
350 \\
251\end{array}$ & $\begin{array}{l}\text { Persistent ketonuria. Liver } \\
\text { function tests normal. } \\
\text { Weight reduced since April, } \\
1955\end{array}$ \\
\hline 8 & $\begin{array}{l}\text { Jan., } 1955 \\
\text { Mar., } 1955 \\
\text { Oct., } 1955\end{array}$ & $\begin{array}{r}122 \\
82 \\
179\end{array}$ & $\begin{array}{l}340 \\
215 \\
394\end{array}$ & $\begin{array}{l}206 \\
105 \\
276\end{array}$ & $\begin{array}{l}\text { Loss of } 7 \text { lb. weight in six } \\
\text { months. Low-starch diet } \\
\text { Jan.-March, 1955 }\end{array}$ \\
\hline 15 & $\begin{array}{l}\text { Mar., } 1954 \\
\text { Sept., } 1954 \\
\text { Jan., } 1955\end{array}$ & $\begin{array}{r}145 \\
95 \\
101\end{array}$ & $\begin{array}{l}225 \\
217 \\
190\end{array}$ & $\begin{array}{r}178 \\
93 \\
122\end{array}$ & Weight reduced since March, \\
\hline 67 & $\begin{array}{l}\text { Nov., } 1955 \\
\text { May, } 1956\end{array}$ & 94 & $\begin{array}{l}192 \\
180\end{array}$ & $\begin{array}{r}135 \\
96\end{array}$ & $\begin{array}{l}\text { Loss of } 10 \text { lb. by diet in six } \\
\text { months between tests }\end{array}$ \\
\hline
\end{tabular}

* These figures have been corrected for non-glucose reducing substances by subtracting $15 \mathrm{mg} . \%$ from the recorded values. 
Further evidence for a potential relationship between oxyhyperglycaemic curves and impaired glucose tolerance is shown by the records of patients 8, 15, and 67 in Table VIII. Each of these patients initially showed pronounced impairment of glucose tolerance, but as a result of restriction of dietary carbohydrate the two-hour values became normal though the peaks remained elevated.

\section{Discussion}

On the basis of the most recent glucose tolerance test Joslin would consider 34 of the 48 patients in Groups $\mathrm{C}$ to $\mathrm{H}$ to be diabetic, whereas Lawrence would make such a diagnosis on only 13 . Their disagreement is almost confined to patients in Groups $\mathrm{E}$ and $\mathrm{F}$, i.e., the oxyhyperglycaemic groups $(40 \%$ of the total), since Lawrence regards a normal two-hour level as excluding diabetes whereas Joslin regards an abnormal peak or fasting level as diagnostic in themselves. Although patients in this series are not representative of cases of symptomless glycosuria as a whole, less than a quarter of them were specially selected on account of previous difficulty in diagnosis. It is clear that a more definite evaluation of the significance of the oxyhyperglycaemic curves is of considerable importance.

Thirty-nine patients with glycosuria have had more than one glucose tolerance test, and in all have received a total of 113 tests. Taking different curves from the same patient, Joslin would diagnose as both diabetic and non-diabetic $31 \%$ of the patients, and Lawrence $33 \%$. This may be explained partly by errors in glucose estimation, and partly by physiological and pathological variation in the patients, but it emphasizes the difficulty of confident diagnosis of these cases.

The difficulties are further accentuated by the differences in probable diagnosis resulting from classification on the basis of the capillary blood $50 \mathrm{~g}$. oral glucose tolerance test and the venous blood $1.75 \mathrm{mg} . / \mathrm{kg}$. oral glucose tolerance test. The effect of increasing the dose of glucose above $30 \mathrm{~g}$. is generally regarded as causing no effect on the peak value reached but to extend slightly the period of hyperglycaemia (Maclean and de Wesselow, 1921; Mosenthal and Barry, 1950). We suspect that the difference in the two-hour value may be considerable, and that this probably accounts for the difference of opinion between Joslin and Lawrence on the value of the two-hour figure in diagnosis. The relationship between the $50 \mathrm{~g}$. and $100 \mathrm{~g}$. glucose tolerance tests is to be the subject of further work.
Lawrence (1947) had never had cause to regret his statement that a raised peak with normal twohour value was normal glucose tolerance and not diabetes. In our experience we have not seen any such patient develop definite clinical diabetes, but Cases 11, 66, 8, 15, and 67 (Table VIII) seem to confirm our suspicion that patients with a normal two-hour value and high peak form a heterogeneous group, viz., patients with rapid absorption of glucose, patients with mild impairment of glucose tolerance, and patients with absorption which is relatively rapid but within normal range and whose ability to metabolize glucose is relatively poor but within normal range.

The finding in the normal control series (Dische et al., 1958) that an inverse relationship exists between peak and two-hour values appears relevant to the diagnosis of normal glucose tolerance in the presence of raised peak values. When absorption is rapid, the supply of glucose in the alimentary tract must diminish quickly ; in the presence of a vigorous homoeostatic mechanism the blood sugar would be expected to fall to levels below the average after a high peak. This is in fact the case in post-gastrectomy patients. The mean two-hour glucose value of seven such patients examined by us was $73 \mathrm{mg} . / 100 \mathrm{ml}$., the two highest being 80 and $83 \mathrm{mg} . / 100 \mathrm{ml}$. (Dische et al., 1958). When our patients with oxyhyperglycaemic curves are divided into two groups, it is found that the peak galactose values in Group $\mathrm{E}$ (two-hour glucose value $80-105 \mathrm{mg} . / 100 \mathrm{ml}$.) do not differ significantly from normal, whereas there is a highly significant difference between the galactose peaks in Group F (two-hour glucose value under $80 \mathrm{mg}$./ $100 \mathrm{ml}$.) and those in the normal control series. This evidence suggests that glucose is rapidly absorbed in those patients included in Group F.

Tables I, II, and III show considerable variation in the height of galactose peaks within each group of patients classified according to their glucose tolerance test results, but the rate of absorption of sugar from the alimentary tract is likely to vary from day to day in any individual. For this reason the galactose tolerance test cannot be expected to give completely reliable information about absorption of glucose during the preceding day's test, and the interpretation of the test in individual cases must not be too rigid. It is believed, however, that an oxyhyperglycaemic patient with a high peak in the galactose tolerance test and a two-hour glucose level below $80 \mathrm{mg}$./ $100 \mathrm{ml}$. is much less likely to have impaired glucose tolerance than a patient with an abnormally high peak glucose, high normal two-hour 
glucose values $(80-105 \mathrm{mg} . / 100 \mathrm{ml}$.), and a low galactose peak. The latter patient is abnormal in three ways: (a) He has an abnormally high peak ; (b) he does not show the normal inverse relationship between peak and two-hour glucose value ; $(c)$ he presents no evidence of a tendency to rapid absorption of sugar by the galactose tolerance test. It must be borne in mind that mildly impaired glucose tolerance may be a progressive disease in only a very few cases, and may not, even if continued for many years, cause any adverse effects on the patient's health. A large-scale controlled follow-up is necessary to elucidate this point.

An examination of Tables I-III confirms the widely held belief that where the fasting blood glucose level is definitely raised there is impairment of glucose tolerance, but on the other hand pronounced impairment may be present with a normal fasting blood sugar.

Cases 14 and 39 have most unusual findings in common. The results of repeated glucose tolerance tests on them are shown below.

\begin{tabular}{|c|c|c|c|c|c|}
\hline Case No. & Date & & F. & P. & 2 \\
\hline 14 & $\begin{array}{l}\text { June, 1939* } \\
\text { Aug., 1939* } \\
\text { May, 1942* } \\
\text { July, 1949* } \\
\text { April, 1955 } \\
\text { Nov., 1953 .. } \\
\text { May, 1954 . } \\
\text { May, 1955 .. } \\
\text { Feb., 1956 .. }\end{array}$ & $\begin{array}{l}\cdots \\
\cdots \\
\cdots \\
\cdots \\
\cdots \\
\cdots \\
\cdots\end{array}$ & $\begin{array}{r}147 \\
70 \\
80 \\
60 \\
72 \\
97 \\
85 \\
88 \\
93\end{array}$ & $\begin{array}{l}217 \\
230 \\
220 \\
140 \\
255 \\
157 \\
173 \\
172 \\
257\end{array}$ & $\begin{array}{r}132 \\
90 \\
50 \\
167 \\
125 \\
134 \\
91 \\
48\end{array}$ \\
\hline
\end{tabular}

* Corrected to " true glucose " values by subtracting $15 \mathrm{mg} . / 100 \mathrm{ml}$. for non-glucose reducing substances.

Both patients were symptomless, had very high galactose peaks (Case 14, $130 \mathrm{mg} . / 100 \mathrm{ml}$., Case $39,132 \mathrm{mg} . / 100 \mathrm{ml}$. in May, 1955 , and $164 \mathrm{mg} . /$ $100 \mathrm{ml}$. in February, 1956), and were both extraordinarily thin men (83 and $78 \%$ expected weight respectively). Clinically neither had thyrotoxicosis. Case 39 had a serum cholesterol level of over $300 \mathrm{mg} . / 100 \mathrm{ml}$. (estimated three times during one week). His serum alkaline phosphatase, bilirubin, and thymol turbidity were normal. He responded positively to cortisone. These tests were not performed in Case 14. Both were probably suffering from the same defect which is perhaps a disturbance of fat metabolism or latent liver disease. If a disturbance of fat metabolism is the cause, then they may be analogous to Lawrence's remarkable case of lipo-atrophic diabetes (Lawrence, 1946). Their galactose tolerance curves may be high in antithesis to the flat galactose curves observed in the obese (Dische et al., 1958). Unfortunately we have been unable to find " normal controls" comparably under weight.
The results with the glucose tolerance test modified with cortisone are strikingly less dramatic than those described by Fajans and Conn. They found some rise in the two-hour level after cortisone in 32 of their 36 diabetics and in all of their eight "probable diabetics" (Fajans, 1956), whereas only six of our nine probable diabetics showed any rise, and in two of these the rise was negligible. The discrepancy may be due to the fact that only five of all our patients but most of those of Fajans and Conn had a family history of diabetes. A C.G.T.T. was performed on three of our patients with a diagnosis of probable clinical diabetes (Cases 1C, 2C, and 9) and none gave a definite positive response: the result in Case 9 was clearly negative. For this reason the cortisone glucose tolerance test in our hands appears insufficiently sensitive to assess the significance of glycosuria associated with borderline glucose tolerance.

\section{Summary and Conclusions}

Sixty-five patients with a history of glycosuria have been examined by the oral glucose and the galactose tolerance tests. A cortisone-modified glucose tolerance test has been performed on 27 glycosuric patients.

The oral glucose tolerance test frequently gives equivocal results in the investigation of cases of symptomless glycosuria. In the presence of a normal fasting blood glucose, both the peak and the two-hour blood glucose level should be used in assessment of tolerance. A high peak associated with a two-hour level which is below the average normal is probably caused by rapid absorption of glucose from the alimentary tract and confirmatory evidence may be obtained with the galactose tolerance test. When the peak is high and the two-hour glucose is within the normal range but above the normal average, impairment of glucose tolerance should be suspected, especially in the presence of normal galactose tolerance.

The cortisone-modified glucose tolerance test of Fajans and Conn has been found of no value in the investigation of this series of cases of symptomless glycosuria.

We wish to thank the Director General of Medical Services for his permission to publish this paper, Dr. P. Armitage of the Statistical Research Unit, London School of Hygiene and Tropical Medicine, for his help and advice, Sergeant Phillips for his technical assistance, and the many volunteer subjects for their patience and tolerance. 
REFERENCES

Dische, S. (1955). J. clin. Path., 8, 253.

- Stamm, W. P., and Goudie, R. B. (1958). Ibid., 11, 350.

Dunlop, D. M. (1954). Brit. med. J., 2, 383.

Fajans, S. S. (1956). Personal communication. and Conn, J. W. (1954). Diabetes, 3, 296.

Joslin, E. P., Root, H. F., White, P., and Marble, A. (1952). Treatment of Diabetes Mellitus, 9 th ed., p. 154. Kimpton, London.

Laughton, N. B., and MacCallum, A. B. (1932). Proc. roy. Soc. B., 111,37 .

Lawrence, R. D. (1936). Brit. med. J., 1, 526.
Lawrence, R. D. (1946). Lancet, 1, 724 and 773. (1947). Med. Clin. N. Amer., 31, 289.

Loubatières, A. (1954). Experimental Diabetes, A Symposium, p. 109. Blackwell, Oxford.

Maclean, H. (1922). Modern Methods in the Diagnosis and Treatment of Glycosuria and Diabetes, 1st ed., p. 45. Constable, London.

- and Wesselow, O. L. V. de (1921). Quart. J. Med., 14, 103.

Mosenthal, H. O. (1947). Med. Clin. N. Amer., 31, 299.

- and Barry, E. (1950). Ann. intern. Med., 33, 1175.

Moyer, J. H., and Womack, C. R. (1950). Amer.J. med. Sci., 219, 161.

Ricketts, H. T. (1947). Med. Clin. N. Amer., 31, 267. 